Agro-Science Journal of Tropical Agriculture. Food, Environment and Extension Volume 7 Number 3 September 2008 po. $199-205$

ISSN $1119-7455$

\title{
ANALYSIS OF FOOD SECURITY STATUS AMONG FARMING HOUSEHOLDS IN JERE LOCAL GOVERNMENT OF BORNO STATE, NIGERIA
}

\author{
Idrisa, Y.L., Gwary. M.M. and Shehu H. \\ Department of Agricultural Economics and Extension, University of Maiduguri Maiduguri, \\ Nigeria.
}

\begin{abstract}
This study analyzed food security status among farming households in Jere local government area (LGA) of Borno state in north-eastern Nigeria. Primary data were collected from 120 households selected through multi-stage sampling procedure. The data were analyzed using frequency, percentage, he ad count method, food security gap and squared food security gap. The result of analysis indicated that $45 \%$ of the respondents fell within the active age bracket of $40-49$ years, more than half (52\%) had only primary/Quranic education with a high proportion (57\%) engaged in farming as a primary occupation. The family size of $40 \%$ of the respondents was between 7-9 persons, with estimated annual income of the majority $(87 \%)$ less than or equal to $\$ 135,000(\$ 100)$ per annum. The incidence of food insecurity was high among the age bracket of 40-49 years (27.5\%) but the depth and severity was higher (0.24 and 0.41 respectively) among the age group of 50 years and above. Also, households with large family size, low income level and low level of education were mostly affected by food insecurity condition. Eating once a day, allowing children to eat first and buying food on credit were among the coping strategies adopted by the respondents. Based on the result, the study recommended that: farmers be provided with informal education through extension service, improve nutritional awareness in the study area, non-farm income earning opportunities for the households and improved access to extension be generated.
\end{abstract}

Key words: Analysis, Food, Security, Households, Jere.

\section{INTRODUCTION}

It is a widely accepted fact that food is a basic necessity of life. Its importance at the household level is obvious since it is a basic means of sustenance. Adequate intake of quality food is a key requirement for healthy and productive life. Helen (2002) asserted that food is useful for maintaining political stability, and insuring peace among people while food insecurity can result in poor health and reduced performance of children. Shala and Stacey (2001) found that many countries experience food insecurity with food supplies being inadequate to maintain their citizens' per capita consumption. They also found that sub-Sahara Africa was the most vulnerable region. The average amount of food available per person per day in the region was 1,300 calories compared to the world wide average of 2,700 calories. F.A.O.
(2004) concluded that Africa has more countries with food insecurity problems than any other region.

Food security in a broad sense consists of having at all times an adequate level of basic products to meet increasing consumption demand and mitigate fluctuations in output and prices. According to Moharjan and Chhetri (2006), food security is widely seen as access by all people at all times to enough food tor an active life, while food insecurity is the inability of a household or individuals to meet the required consumption levels in the face of fluctuating production, price and income. At the national level, food security exists when all people at all times have the physical and economic access to sufficient, safe and nutritious food to meet their dietary needs and food preferences for active and healthy life, while at 
the household level, food security implies physical and economic access to food that is adequate in terms of quantity, safety and $\mathrm{c} u \mathrm{u}$ tural accessibility, to meet each person's need (Ingawa, 2002).

A country can be said to be enjoying food security when people's fear of not having enough to eat is removed and the most vulnerable group, namely women and children, in the marginal areas have access to adequate quality of food they want. According to the World Bank (1986), food security refers to access to food resources by each individual at all times for healthy and active life.

Food demand in Nigeria has generally grown faster than either food production or total supply. C. B. N. (2001) reported that the rate of increase in food production of 2.5 percent per annum does not keep pace with the annual population growth rate of 2.8 percent per annum. Fakiyesi (2001) also maintained that Nigeria's domestic food supply has been far short of the need of the population. This could result in reduced consumption among the poor. The urban poor in particular are lacking in education, basic technical skills and employment. Consequently these category of persons belong to the low income groups and are therefore most vulnerable to food insecurity. Given the high cost of social services, nutritional level and food purchasing capacity tend to deteriorate as relatively large proportion of income goes to meeting these social services (Olayemi, 1998). Ali (1994) stated that the African poor have common characteristics of facing the most severe difficulties in relation to production of food and access to food market which make them most vulnerable to food security crisis.

In Nigeria, the issue of food in security is of a major concern. This is particularly more in the northern Sudan Savannah and Sahel zones which have the highest prevalence of under nutrition (FAO, 1998) and where the study area lies. Fakiyesi (200l) also estimated that about $66 \%$ of Nigeria's populations live below poverty line as portrayed by their level of food security.

Against the above background, this research was undertaken to analyse the food security status among farming households in Jere local government of Borno state. The specific objectives of the study were to:

(i) examine the socio-economic characteristics of farming households in the study area; (ii) assess the food security status of farming households in the study area; and

(iii) identify coping strategies against food insecurity in the study area.

\section{MATERIALS AND METH̊ODS}

This study was conducted in Jere local government area of Borno state in Nigeria. The study area has a population of 211, 204 (FGN, 2007) and the major activity of the people is farming. The major crops produced in the area include; millet, cowpea, groundnuts, rice and vegetables. Multistage sampling technique was used for the study. Three Extension Blocks (EBs) were selected through simple random sampling technique out of the five extension blocks in the area. Stage two involved selection of two villages out of the five villages from each of the three extension blocks selected in stage one giving a total of six villages, while the final stage involved the selection of twenty households using simple random sampling technique from each of the six villages selected in stage two giving a total of 120 houscholds used for the study. Structured questionnaire was used to collect primary data from the 120 respondents.

Frequency distribution and percentage were used to analyse objective one, while Head Count Method (HCM), Food Insecurity Gap (FIG) and Squared Food Insecurity Gap(SFIG) were used to capture the severity of food insecurity status of the households as used by Maharjan and Chhertri (2006). Food balance sheet and aggregate household calorie consumption was constructed for the purpose of this research, while food security condition was calculated based on calorie requirement according to gender and age of household mernbers as recommended by FAO (2004).

Head count method was used to measure food security status and is expressed as:

$\mathrm{FII}=(\mathrm{FIH} / \mathrm{TH}) \times 100 \ldots \ldots \ldots \ldots \ldots . .$.

Where

FII = Food Insecurity Index

FIH = Number of Food Insecure Houscl. As

$\mathrm{TH}=$ Total Households under study :

Food Insecurity Gap measures the depth of food insecurity and is expressed as:

$\mathrm{FIG}_{1}=\left(\mathrm{TCR}_{\mathrm{i}}-\mathrm{TCC}_{\mathrm{i}}\right) / \mathrm{TCR}_{\mathrm{i}} \mathrm{X} 100 / 1$

Where

$\mathrm{FIG}_{\mathrm{i}}=$ Food Insecurity Gap of $\mathrm{i}^{\mathrm{th}}$ food insecure household

$\mathrm{TCR}_{\mathrm{i}}=$ Total Calorie Requirement for $\mathrm{i}^{\mathrm{ith}}$ food insecure household 
$\mathrm{TCC}_{\mathrm{i}}=$ Total Calorie Consumption. by $i^{\text {th }}$ food insecure household

Hence, the total food insecurity gap is expressed as:

$\mathrm{TFIG}=\sum\left\{\left(\mathrm{TCR}_{\mathrm{i}}-\mathrm{TCC}_{\mathrm{I}} / \mathrm{TCR}_{\mathrm{i}}\right\} / \mathrm{FIH}\right.$

Squared Food Insecurity Gap, which indicates severity of food insecurity among the food insecure house hold is given as:

$\mathrm{SFIG}=\sum\left(\mathrm{FIG}_{\mathrm{i}) 2} / \mathrm{FIH}\right.$.

\section{RESULTS AND DISCUSSION}

Socio-economic characteristics of households

Entries in Table 1 show that majority $(45.0 \%)$ of the respondents were between 40 and 49 years of age, while $40.0 \%$ were within the age range of $30-39$ years of age. Those that were within the age range of 20-29 years and 50-59 years accounted for $3.0 \%$ and $12.0 \%$ respectively. By implication about $85 \%$ were within their middle age of $30-49$ years. Within this age range, the respondents are expected to very active on the farm and more responsive to agricultural extension programmes. This could also lead to a boost in agricultural activities as Anyanwu et. al., (2001) recognized that young people are more likely to be energetic and have the capacity to use innovation. The study also showed that about half $(52 \%)$ of the respondents had primary or Qur'anic education; 38.0\% had either secondary school or teachers' grade II certificate. This situation has serious consequences on the level of agricultural production and hence food security at household level. Bzugu et. al, (2005) and Idrisa et. al, (2007) had earlier recognized that low level of formal education among farmers make the introduction of improved agricultural technologies by extension agents difficult. As it could be seen from Table 1, more than half $(57.0 \%)$ of the respondents are engaged in farming as primary occupation with majority of them operating at subsistence level. Record of family size also revealed that $74.0 \%$ of the respondents had more than six persons per family, while majority $(87.0 \%)$ of them depended on annual income of not more than $\$ 1350$ ( $\$ 100$ ).

Both family size and level of income could affect the food security status at the family level. According to Olayemi (1998) and Ali (1994), the urban poor do spend a high proportion of their income on social services and only a little could be left for the purchase of food, or investment in production. The consequence is more serious when the income is 'low' and family size is 'high' as portrayed by this study.

Table 1: Percentage distribution of respondents on the basis of their socio-economic characteristics $(n=120)$

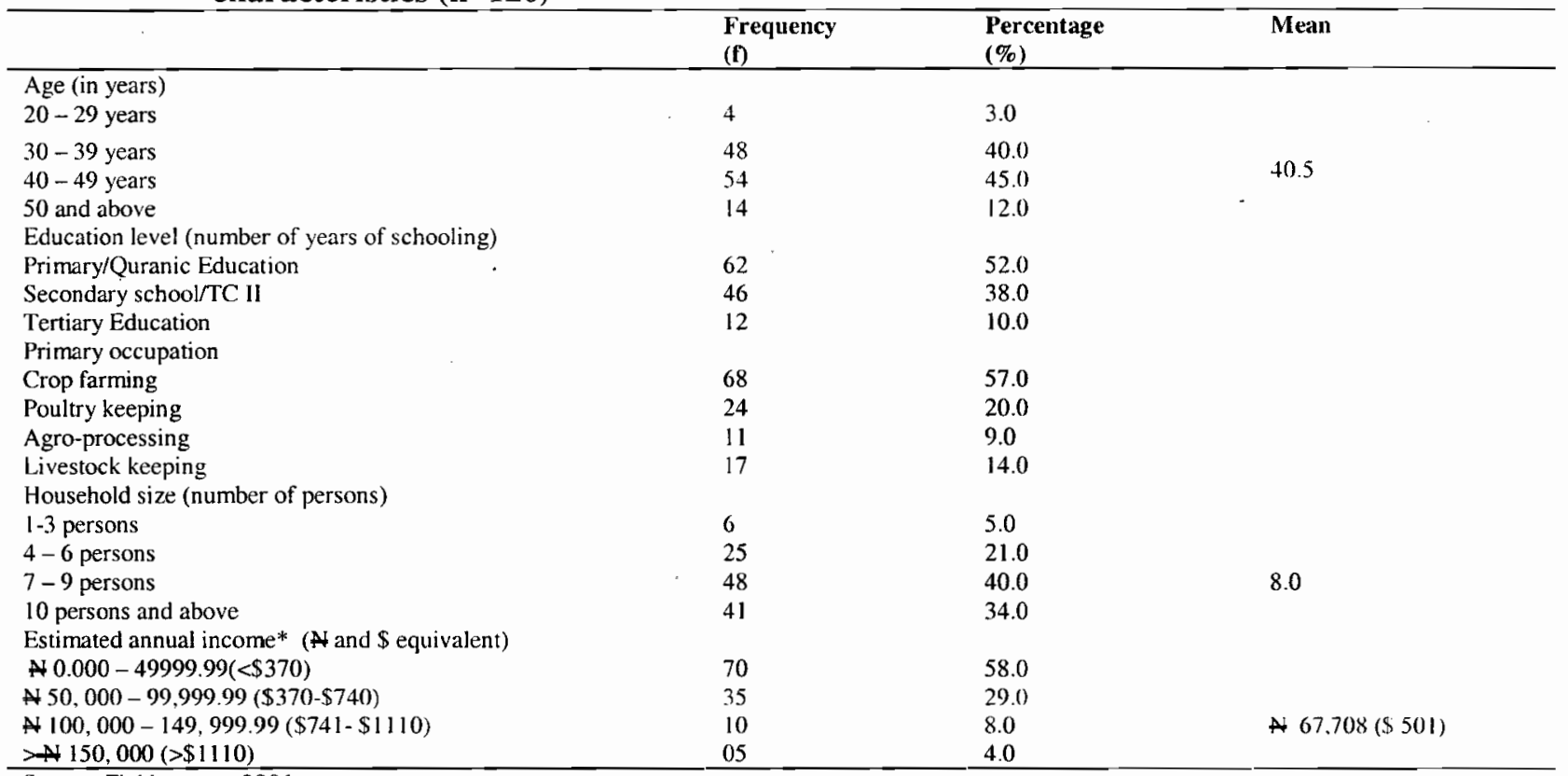

Source: Field survey, 2006.

- $\$ 1.00=\mathrm{A} 135.00$

- $\$ 1.00=\mathrm{A} 135.00$ 


\section{Food Security Status of Respondents}

The results reveal that the incidence of food insecurity was high within the age bracket of 40-49 years (27.5\%) but the severity and depth was higher within the age bracket of 50 years and above. The age bracket within 40-49 years fell under potential food insecurity group with less than $50 \%$ calorie deficiency, while those within the age bracket of 50 years and above fell within chronic food insecurity group with more than $50.0 \%$ calorie deficit. This agrees with the findings of FAO (2004) that about $4.7 \%$ of the population consume less than their dietary requirements. This may be attributed to the old age which makes them less active, less productive and unable to look for jobs; as such, the severity is higher among this category.

The incidence of food insecurity is also high among households in which the heads of family had low level of education (30.8\%); likewise, the depth and severity of food insecurity ( 0.3 and 0.29 , respectively), with the incidence being less among households headed by highly educated persons. This agrees with the findings of Amaza et.al. (2006), which suggests that the higher the educational level of a head of household, the more the food security status of the family.

The results also show that the incidence, depth and severity were higher among families with large household size than among those with small household size. This is obvious because the larger the household size, the greater the responsibilities, especially, in a situation where many of the household members do not generate any income but only depend on the household head. This is in consonance with the findings of Maharjan and Chhetri (2006) that food secure households have small size and low dependency ratio.

The primary occupation of respondents also reveals that the incidence of food insecurity was high among those who were involved in agro-processing $(25.0 \%)$ as their primary occupation compare to the dismal (6.7\%) among those involved in poultry keeping and $13.3 \%$ among those involved in crop farming als their primary occupation. However, the depth of food insecurity was higher among livestock keepers $(0.25)$ as against the dismal $(0.10)$ anong those involved in crop farming. Severity of food insecurity was also found to be higher among those involved in livestock keeping $(0.34)$ and least among crop farmers $(0.08)$. The depth and severity of food insecurity was found to be higher among those involved in livestock keeping.

Income level of respondents reveals that households with income level of less than $\$ 0$ 49,999.99 had the highest incidence, depth and severity of food insecurity status of $31.7 \%, 0.36$ and 0.41 , respectively, while the incidence in particular is less among households with income level greater than $\$ 150,000(4.2)$. This category also had the least depth $(0.13)$. The implication of this finding is that accessibility to good food. in the volume to subdue hunger and taken in the right quality i.e. containing the correct nutritional requirement is low among a vast majority of the households. As such, nutrients-related diseases are likely to become rampant. Thus, consumption below the minimum level of calorie requirement indicates food insecurity condition. Helen (2002) opined that about 800 million people suffer from malnutrition and most of those under-nourished in low income countries like Nigeria. 
Table 2: Incidence, depth and severity of food insecurity according to socio-economic characteristics of respondents $(n=120)$

\begin{tabular}{|c|c|c|c|c|}
\hline Characteristic & $\begin{array}{l}\text { Incidence of } \\
\text { Insecurity }(\%)\end{array}$ & Food & Depth of Food Insecurity & $\begin{array}{l}\text { Severity of Food } \\
\text { Insecurity }\end{array}$ \\
\hline \multicolumn{5}{|l|}{ Age (years) } \\
\hline $20-29$ & 1.7 & & 0.08 & 0.38 \\
\hline $30-39$ & 20.0 & & 0.20 & 0.20 \\
\hline $40-49$ & 27.5 & & 0.18 & 0.12 \\
\hline 50 and above & 14.2 & & 0.24 & 0.41 \\
\hline \multicolumn{5}{|l|}{ Educational Level (years of schooling) } \\
\hline Primary School & 30.8 & & 0.30 & 0.29 \\
\hline Sec. School/TC II & 20.0 & & 0.17 & 0.14 \\
\hline Tertiary level & 12.5 & & 0.15 & 0.18 \\
\hline \multicolumn{5}{|l|}{ Household Size (number of persons) } \\
\hline $1-3$ & 4.2 & & 0.1 & 0.20 \\
\hline $4-6$ & 10.0 & & 0.19 & 0.36 \\
\hline $7-9$ & 15.1 & & 0.29 & 0.56 \\
\hline 10 and above & 34.2 & & 0.50 & 0.73 \\
\hline \multicolumn{5}{|l|}{ Primary Occupation } \\
\hline Crop farming & 13.3 & & 0.10 & 0.08 \\
\hline Poultry keeping & 6.7 & & 0.14 & 0.29 \\
\hline Agro-processing & 25.0 & & 0.22 & 0.19 \\
\hline Livestock keeping & 18.3 & & 0.25 & 0.34 \\
\hline \multicolumn{5}{|l|}{ Estimated Annul Income (AH } \\
\hline$\wedge 0.000-49999.99(<\$ 370)$ & 31.7 & & 0.36 & 0.41 \\
\hline$\$ 50,000-99,999.99(\$ 370-\$ 740)$ & 16.7 & & 0.23 & 0.32 \\
\hline N $100,000-149,999.99(\$ 741-\$ 1110)$ & 10.8 & & 0.15 & 0.23 \\
\hline$>-150,000(>\$ 1110)$ & 4.2 & & 0.13 & 0.40 \\
\hline
\end{tabular}

Source: Field Survey, 2006.

- The result was calculated based on recommended calorie intake of $2654 \mathrm{kcal}$ for developing countries as recommended by FAOSTAT database (FAO, 2005).

Copping strategies against food insecurity

Table 3 shows that that majority $(68.3 \%)$ of the respondents often allowed children to eat first, $64.2 \%$ often bought food on credit, while $57.5 \%$ resorted to eating once a day.
Moreover, $58.3 \%$ of the respondents occasionally resorted to eating wild fruits. Eating of wild fruits is occasional to the nature of the study area being an urban center hence, the availability of wild fruits is limited.

Table 3: Percentage distribution of respondents according to strategies against food insecurity $(n=120)$

\begin{tabular}{|c|c|c|c|c|}
\hline Coping strategy & $\begin{array}{l}\text { Very often } \\
(\%)\end{array}$ & Regularly (\%) & Occasional (\%) & Never(\%) \\
\hline Eating once a day & 57.5 & $\overline{12.5}$ & 24.2 & 5.8 \\
\hline Allowing children to eat first & 68.3 & 15.0 & 15.0 & 1.7 \\
\hline Eating wild fruits & 10.0 & 24.2 & 58.3 & 7.5 \\
\hline Selling of assets & 38.3 & 11.7 & 41.7 & 8.3 \\
\hline Buying food on credit & 64.2 & 20.0 & 10.8 & 5.5 \\
\hline Picking of left over food at social functions & 46.7 & 22.5 & 25.0 & 5.8 \\
\hline
\end{tabular}

Source: Field Survey, 2006.

- Multiple responses existed, hence $\%>100$

Table 4 indicates that about half $(48.0 \%)$ of the respondents engaged in handicraft as means of improving food insecurity status, $30.0 \%$ engaged in fishing mainly in Lake Alau and the shores of Lake Chad, $15.0 \%$ sold farm by-products and seven percent joined cooperative societies. All these activities, except the joining of cooperative societies are done during the off-farming season.
The steps taken here are in line with the United Nations (2002) report, which indicated that during food crisis, affected population adopt a variety of copping mechanisms to survive such strategies may include finding additional food or income or even, migration etc. 
Table 4: Percentage distribution of respondents according to strategies adopted to improve food security ( $n=120)$

\begin{tabular}{llll}
\hline Strategy & Frequency $(\mathbf{F})$ & Percentage (F) \\
\hline Hand craft & 58 & 48.0 & 1 \\
Fishing during dry season & 36 & 30.0 & 1 \\
Sales of farm by product & 18 & 150 & 3 \\
Joining cooperative societies & 8 & 70 & 4 \\
\hline
\end{tabular}

Source: Field survey, 2006

\section{CONCLUSION AND RECOMMENDATION}

The paper assessed food security status among farming households in Jere local government area of Borno state. Results of the study indicated that more than half of the respondents did not have up to secondary school level of education, with majority $(57 \%)$ engaged in "peasantry" farming and $74 \%$ had more than seven persons per family while majority $(58 \%)$ had income of less than $\$ 50,000$ per annum. It was also found that households whose heads had low level of education $(30.8 \%)$, those having large number of persons per family $(34.2 \%)$ and those whose heads had low level of income $(31.7 \%)$ were worse affected by incidence, depth and severity of food insecurity. The coping strategies adopted included eating once per day, allowing children to eat first, eating wild fruits and buying food on credit. In addition, the respondents adopted some mechanisms to improve their food security statuses. These included handcraft and fishing during off-season. To improve food security situation in the study area requires paying proper attention to the following recommendations.

(i) Farmers should be given informal education through extension service with a view to enhance their understanding of modern agricultural production techniques and easy access to improved technologies to boost agricultural production.

(ii) Home economics component of agricultural extension should be strengthened with a view of educating farmers and rural households on the use of local resources to improve the nutritional status of their households.

(iii) The poverty alleviation programme of government should focus on how to boost non-farm income of farmers by training the farmers on off-farm businesses so as to boost income and subsequently enhance food security.

(iv) The coping mechanisms embarked upon by the respondents have short term effect. Therefore, there is a need to improve on access to income generating activities that are more sustainable.

\section{REFERENCES}

Ali, D. (1994): Executive Summary and Introduction: Food and Food Security in Africa. Food and Agricultural Organisation of the United Nations, Rome, Italy.

Amaza, P.S., Umeh, J.C., Hesen, J. and Adejobi, A.O. (2006). Determinants and Measurement of Food Insecurity in Nigeria: Some Empirical Policy Guide. Paper Presented at the International Association of Agricultural Economists' Conference, Gold Coass. Australia, August 12-26.

Anyanwu, A. C., Agwu, A. E. and Musa, A. P. (2001): Adoption of Gender Specific Innovation by Women in State, Joumal of Agricultural Extension 5, 64-72.

Byerlee, D. and C. K. Eicher eds (1997): Africa's emerging maize revolution. Boulder, ColoU.S.A. Iynne Reiner.

Bzugu, P.M., Gwary, M.M. and Idrisa, Y. (2005). Impact of Extension Services on Rural Poverty Alleviation among Farmers in Askira Uba Local Government Area, Borno State. Sahela Analyst, $7(1 \dot{\&} 2), 94-102$.

C.B.N. (2001): Economic and Financial Review vol. 36 No. 1 .

F.A.O. (1998):Food and Agricultural Organization of the United Nations. Energy for sustainable Development and Food Security in Africa. Food and Agricultural Organisation of the United Nations, Rome, Italy.

F.A.O. (2004). Food and Agricultural Organization of the United Nations. The State of Food Insecurity in the World: Monitoring progress toward the world food submit and Millenium Development Goals. Rome, F.A.O.

F.A.O. (2005). Food and Agricultural Organization of the United Nations. FAOSTAT, Statistical Database. Rome, FAO.

F.G.N. (2007). Federal Republic of Nigeria Official Gazette: Legal Notice on Publication of the Details of the Breakdown of the National and State Totals of the 2006 Census. 
Fakiyesi, O. M. (2001): "Encouraging Growth to reduce Poverty in Nigeria". In C.B.N.: Economic and Financial Review vol. 39 No. 2. $\mathrm{Pp} 132-137$.

Helen, H. J. (2002): Food Insecurity and the food stamp Programme. American Journal of Agricultural Economics. Vol. 84 No. 5 Pp. $1215-1218$.

Idrisa, Y.L., Gwary, M.M. and Ibrahim, A. (2006): Determinants of Adoption of Cassava Farming Technologies in Mubi north Local Government Area of Adamawa State Nigeria. Journal of Production Agriculture and Technology, 2(2): 26-36.

Maharjan, K.L. and Chhetri, A.K. (2006). Household Food Security in Rural Areas of Nepal: Relationship between socio-economic characteristics and food security status. Paper Presented at the International Association of Agricultural Economists' Conference, Gold Coast, Australia, August 12-26.
Ingawa, S. A. (2002): Keynote address at the $8^{\text {th }}$ Annual conference of the Agricultural Extension Society of Nigeria held in Benin City, 16 - 19 September, In Olowu T. A. (ed). Processings of the Agricultural Extension Society of Nigeria

Olayemi, J. K. (1998): The Nigerian Food Equation towards a Dynamic Equilibrium, University of Ibadan Inaugural Lecture. No. 167.

Shala and Stacey, (2001): United States Department of Agriculture: Economic Research Service. Food Security Assessment, Regional Overview Information Bulletin.

United Nations Integrated Regional Information Network (2002): Food crises Aggravates spread of HIV

World Bank (1986): In Olowu. T. A. (ed) Proceedings of the 8th Annual Conference of the Agricultural Extension Society of Nigeria; held in Benin City, September 16-19. 